\title{
Comparison of dynamic response of isolated and non-isolated continuous girder bridges subjected to near-fault ground motions
}

\author{
Wen-I Liao ${ }^{\mathrm{a}, *}$, Chin-Hsiung Loh ${ }^{\mathrm{b}}$, Bor-Han Lee ${ }^{\mathrm{a}}$ \\ a Department of Civil and Environmental Engineering, National University of Kaohsiung, No. 700, Kaohsiung University Road, \\ Kaohsiung 811, Taiwan \\ b Department of Civil Engineering, National Taiwan University, Taipei, Taiwan
}

Received 21 February 2003; received in revised form 19 July 2004; accepted 27 July 2004

\begin{abstract}
The dynamic response of seismic isolated continuous girder bridges subjected to either near-fault or far-field ground motions is compared to the non-isolated ones. Near-fault earthquake ground motion data are collected from the 1999 Taiwan Chi-Chi earthquake. The earthquake data recorded at the same sites from other events serve as far-field ground motions. Typical three-span continuous concrete box girder bridges designed under Taiwan seismic design specifications of highway bridges are adopted for this study. These bridges are assumed straight, founded on rigid rock and only the longitudinal response is considered. Parametric studies for the dynamic responses of isolated bridges by input near-fault ground motions are developed. The PGV/PGA value of near-fault earthquake records is identified as the key parameter governing the bridge response.
\end{abstract}

(C) 2004 Elsevier Ltd. All rights reserved.

Keywords: Isolated bridge; Chi-Chi earthquake; Near-fault

\section{Introduction}

Near-fault ground motions recorded in recent major earthquakes (1994 US Northridge, 1995 Japan HyogokenNanbu and 1999 Taiwan Chi-Chi earthquake) are characterized by a ground motion with large velocity pulse; which expose the structure to high input energy in the beginning of the earthquake. The related study is therefore a very important topic for both the seismological and civil and architectural engineering communities.

Several important factors have been pointed out in previous studies. Bertero et al. [1] analyzed fixed base buildings subjected to ground shaking. Their result showed that the near-fault ground motions with pulses can induce strong responses. Anderson and Bertero [2] studied the correlation between the width of the acceleration pulse and the natural period of the structure.

\footnotetext{
${ }^{*}$ Corresponding author. Tel.: +886-7-5919-222; fax: +886-2-27322223.

E-mail address: wiliao@nuk.edu.tw (W.-I. Liao).
}

They pointed out that if the width of the pulse is larger than the natural period of the structure, the structure might receive severe damage. Hall et al. [3] simulated the $M_{\mathrm{w}}=7.0$ earthquakes on a blind-thrust fault and these artificial pulse ground motions are used as input to study the responses of buildings. They indicated that the demands made by the near-fault ground motions could far exceed the capacity of flexible high-rise and base-isolated buildings. Iwan [4] stated that the rather distinct low-frequency pulses in the acceleration time histories for the near-fault records will result in coherent pulses in the velocity and displacement time histories. For structures subjected to such ground motion, these pulses will propagate through the structure as waves, and the response spectrum analysis may not capture the effect of these pulses. Iwan further proposed the use of drift spectrum for near-fault ground motions. Malhotra [5] studied the response characteristics of near-fault pulse-like ground motions and showed that ground motions with high peak ground velocity (PGV) to peak ground acceleration (PGA) ratios have wide acceleration-sensitive regions in their 
response spectra. This phenomenon will increase the base shear, inter-story drift and ductility demand of high-rise buildings. By investigating the responses of single degree of freedom (SDOF) systems under the near-fault and far-field earthquake motions in the context of spectral regions, Chopra and Chintanapakdee [6] found that for the same ductility factor, the near-fault ground motions impose a larger strength demand than the far-field motions do. Chai and Loh [7] used three types of velocity pulse to determine the strength reduction factor of structures. They found that the strength demand depends on the pulse duration and the ratio of pulse duration to the natural period of the structure. Liao et al. [8] studied the dynamic behavior of a five-span concrete pier bridge subjected to both near-fault and far-field ground motions. Their results also support the similar conclusion that more ductility demands and base shear are caused by near-fault earthquake ground motions than by far-field earthquake ground motions. Nakashima et al. [9] examined the response behavior of steel moment frames subjected to near-fault ground motions recorded in recent earthquakes in Japan, Taiwan and the US, and found that the largest story drifts are all similar among Japanese, Taiwanese and the American near-fault records. Loh et al. [10] carried out a series of experimental studies to develop a regression-based hysteretic model. They used this hysteretic model to study basin effect and near-fault effect of ground motion subjected to ChiChi earthquakes.

The first objective of this paper is to compare the dynamic behavior of seismic isolated continuous girder bridges to the non-isolated ones subjected to near-fault and far-field ground motion excitations. Typical threespan prestressed continuous concrete box girder highway bridges are employed. Their designs comply with the current Taiwan seismic design specifications of highway bridges [11]. Two different pier heights (7.5 and $15.0 \mathrm{~m}$ ) are selected to represent the behaviors of bridge in short-period and intermediate-period range, respectively. To demonstrate the effect of isolation bearings, two types of bridge system have been adopted here for analysis. One of them is the isolated bridge and the other is the non-isolated bridge. For the isolated bridge, the bearing system in longitudinal direction is sliding bearings at the two abutments and leadrubber bearings (LRB) on top of the two piers. The bearing system of the non-isolated bridge in longitudinal direction that there are sliding bearings at the two abutments and moment hinges on top of the two piers. The Chi-Chi earthquake records that displayed a ground motion with apparent velocity pulse was selected to represent the near-fault earthquake characteristics. In this study, the term "near-fault ground motion" is referred to the ground motion record obtained in the vicinity of a fault, with apparent velocity pulse (pulse duration larger than $1.0 \mathrm{~s}$ ), and the PGV/PGA value (unit in second) of which is larger than $0.1 \mathrm{~s}$. For comparison, earthquake ground motions recorded at the same site from other events that the epicenter far away from the site are employed as the far-field ground motions, to illustrate the difference between the far-field and near-fault earthquake characteristics. Only the horizontal component in eastwest direction of the ground motions was utilized as inputs for analyzing the bridge's dynamic behavior.

Another objective of this paper is to study the relation among the parameters of the near-fault earthquake records and the dynamic response characteristics of the isolated bridges. Some important parameters, such as the ratio of PGV to PGA, normalized spectral velocity and the energy of the ground motion, are evaluated in the present study and to discuss the feature of bridges to near-fault ground motions, where the normalized spectral velocity means the response spectral velocity obtained by scaling the PGA of the input ground motion to $1 \mathrm{~g}$. The main contribution of this parametric study is to identify the $\mathrm{PGV} / \mathrm{PGA}$ value govern the bridge response for input near-fault ground motions. It is helpful for the engineering design of seismic isolated bridges.

\section{Bridge modeling and idealization}

Fig. 1 shows the configuration of a three-span highway bridge. The cross-section of the prestressed concrete box girder and the concrete pier are shown in Fig. 2. Two different pier heights $(7.5$ and $15.0 \mathrm{~m})$ are selected here to represent the behavior of bridges in the short-period and intermediate-period range, and named bridge-A for the bridge with pier height $7.5 \mathrm{~m}$ and bridge-B for the bridge with pier height $15.0 \mathrm{~m}$. These bridges are designed according to the current Taiwan seismic design specifications of highway bridges; the total dead load $\mathrm{W}$ which includes the superstructure and the piers is $24.0 \mathrm{MN}$ for bridge- $\mathrm{A}$ and $25.7 \mathrm{MN}$ for bridge- $\mathrm{B}$, the design peak ground acceleration is $0.34 \mathrm{~g}$. The nominal compressive strength of concrete and yield strength of reinforcement are 27.5 and 412 $\mathrm{MPa}$, respectively. The natural periods and design lateral force (base shear) for the non-isolated bridge and

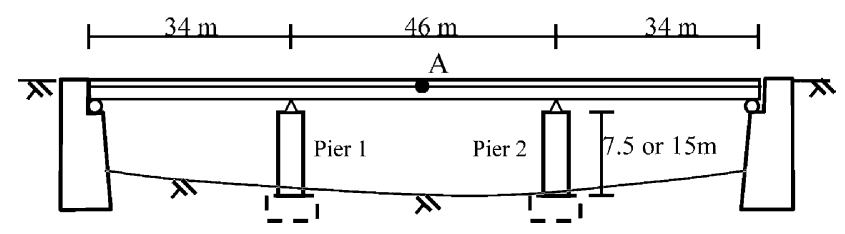

Fig. 1. Configuration of the three-span continuous girder bridge. 
(a)

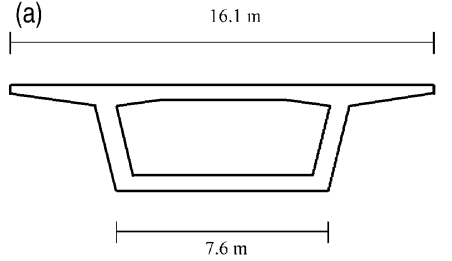

(b)

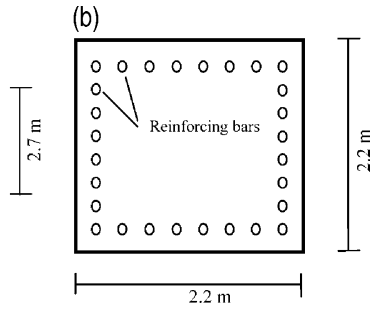

Fig. 2. (a) Cross-section of the continuous girder, (b) cross-section of the concrete bridge pier.

isolated bridge in the longitudinal direction are shown in Table 1. The steel ratios for the piers are $1.40 \%$ for bridge-A and $2.20 \%$ for bridge-B. For the isolated bridge, the designed yield force for each LRB isolator system on the pier is about $2.5 \%$ of the weight of the girder, the post-yielding stiffness adopted herein is $12 \%$ of the initial stiffness. Fig. 3 shows the hysteretic loop and yield surface of this seismic isolator.

The bridges are assumed to stand on rigid foundation, the dynamic soil-structure interaction is neglected and only the longitudinal motion is considered, the transverse and vertical components are ignored. In addition, uniform ground motions are assumed. The concrete box girder is assumed to behave linear-elastically and non-linearities occur only in the concrete piers and lead-rubber bearings (LRB).

Table 1

Properties of analyzed bridges

\begin{tabular}{lll}
\hline & $\begin{array}{l}\text { Bridge-A } \\
\text { (pier height 7.5 m) } \\
\text { longitudinal } \\
\text { direction }\end{array}$ & $\begin{array}{l}\text { Bridge-B } \\
\text { (pier height 15.0 m) } \\
\text { longitudinal } \\
\text { direction }\end{array}$ \\
\hline $\begin{array}{l}\text { Design lateral force } \\
\begin{array}{l}\text { Natural period of } \\
\text { non-isolated bridge (s) } \\
\text { Natural period of } \\
\text { isolated bridge (s) }\end{array}\end{array}$ & $0.199 \mathrm{~W}^{\mathrm{a}}$ & $0.120 \mathrm{~W}^{\mathrm{a}}$ \\
\hline
\end{tabular}

${ }^{\mathrm{a}} \mathrm{W}$ is the dead load of the bridge.
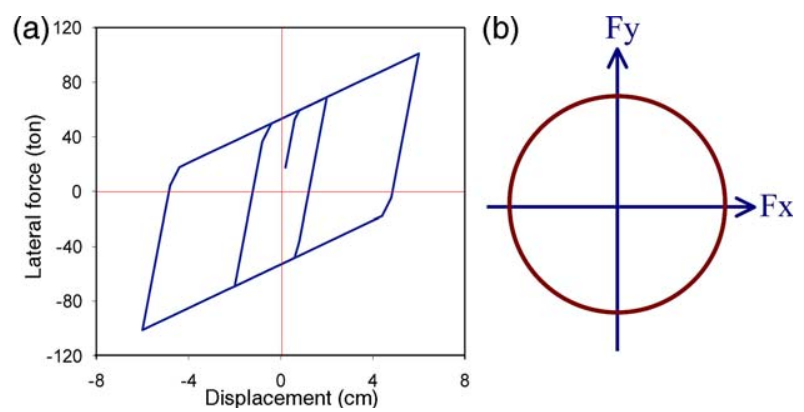

Fig. 3. (a) Lateral force-displacement hysteretic loop, and (b) yield surface in lateral directions of the lead-rubber bearing isolator.
Two new elements are developed and added into the computer program DRAIN-3DX [12] used in this study for dynamic response analysis of the bridge. One is the non-linear slice-fiber model element for modeling the concrete pier behavior; another is the bi-linear model LRB element for modeling the behavior of the isolator. In the analytical model of this bridge, the continuous girder is modeled as the linear elastic element; the concrete piers are modeled as the slice-fiber model element. Therefore, the interaction relationship between axial force and bending moments can be automatically calculated. Each element is divided into slices along the axis of the column member. The slices are further separated into concrete and steel fibers. The strains in these fibers are calculated by the centroidal strain and section curvature with the assumption that plane section remains plane. The concrete stress-strain curve adopted herein is the confined Kent and Park model [13]. According to the research report by Yeh and Mow [14], the results of the force-displacement relationship obtained by the confined Kent and Park model are very close to the experimental data for fullscale bridge column tests. Concrete is assumed incapable of carrying tensile stress. Once cracking occurs, the concrete fiber cannot supply compressive strength until the crack is closed. For the steel fiber, a bi-linear model with a $2 \%$ strain-hardening ratio was adopted to model the stress-strain curve of the reinforcement.

\section{Bridge responses subjected to near-fault and far- field ground motions}

In the study of this section, four near-fault ground motion records were selected as input ground motions from the 1999 Taiwan Chi-Chi earthquake $\left(M_{\mathrm{w}}=7.7\right.$, $M_{1}=7.3$ ). These records are from station numbers TCU052, TCU068, TCU075 and TCU102 [15], respectively. The peak values of ground acceleration and velocity (PGA and PGV), surface projection distance from the site to the fault and the PGV/PGA values are depicted in Table 2. In contrast, another set of earthquake records, which recorded at the same site from other earthquake events with epicenter far away from the site, was selected to illustrate far-field ground motion characteristics. Three earthquake records were selected for each site in this study. The characteristics of those far-field earthquake records are summarized in Table 3.

The acceleration time history and velocity time history of the east-west component (which is approximately normal to the fault) of the near-fault ground motion recorded at station TCU052 are shown in Fig. 4. The far-field ground motion recorded at the same site is also shown in the same figure for compari- 
Table 2

Properties of selected near-fault ground motion record

\begin{tabular}{lllll}
\hline Station & PGA $\left(\mathrm{cm} / \mathrm{s}^{2}\right)$ & PGV $(\mathrm{cm} / \mathrm{s})$ & $\begin{array}{l}\text { Distance to the fault } \\
(\mathrm{km})\end{array}$ & $\begin{array}{l}\text { PGV } / \text { PGA }(\mathrm{s}) \\
\text { duration }(\mathrm{s})\end{array}$ \\
\hline TCU052 & 348.7 & 181.8 & 2.34 & 5.54 \\
TCU068 & 501.6 & 280.2 & 0.49 & 0.521 \\
TCU075 & 325.3 & 116.5 & 0.43 & 0.559 \\
TCU102 & 298.4 & 86.5 & 0.81 & 3.85 \\
\hline
\end{tabular}

Table 3

Properties of selected far-field ground motion record

\begin{tabular}{|c|c|c|c|c|c|c|}
\hline Station & Label & PGA $\left(\mathrm{cm} / \mathrm{s}^{2}\right)$ & PGV $(\mathrm{cm} / \mathrm{s})$ & Magnitude $M_{1}$ & $\begin{array}{l}\text { Epicenter distance } \\
(\mathrm{km})\end{array}$ & $\begin{array}{l}\text { PGV/PGA (s) } \\
\text { (mean value) }\end{array}$ \\
\hline TCU052 & $\begin{array}{l}\text { TCU052F1 } \\
\text { TCU052F2 } \\
\text { TCU052F3 }\end{array}$ & $\begin{array}{l}37.4 \\
13.5 \\
17.5\end{array}$ & $\begin{array}{l}2.39 \\
2.07 \\
1.90\end{array}$ & $\begin{array}{l}5.83 \\
6.50 \\
5.56\end{array}$ & $\begin{array}{l}152.7 \\
104.5 \\
108.3\end{array}$ & 0.109 \\
\hline TCU068 & $\begin{array}{l}\text { TCU068F1 } \\
\text { TCU068F2 } \\
\text { TCU068F3 }\end{array}$ & $\begin{array}{l}16.1 \\
16.1 \\
13.8\end{array}$ & $\begin{array}{l}1.31 \\
2.03 \\
1.86\end{array}$ & $\begin{array}{l}5.83 \\
6.50 \\
5.77\end{array}$ & $\begin{array}{r}157.8 \\
98.5 \\
93.9\end{array}$ & 0.114 \\
\hline TCU075 & $\begin{array}{l}\text { TCU075F1 } \\
\text { TCU075F2 } \\
\text { TCU075F3 }\end{array}$ & $\begin{array}{l}22.6 \\
36.8 \\
23.0\end{array}$ & $\begin{array}{l}0.82 \\
1.24 \\
0.51\end{array}$ & $\begin{array}{l}5.58 \\
5.83 \\
5.56\end{array}$ & $\begin{array}{l}119.8 \\
140.4 \\
107.4\end{array}$ & 0.031 \\
\hline TCU102 & $\begin{array}{l}\text { TCU102F1 } \\
\text { TCU102F2 } \\
\text { TCU102F3 }\end{array}$ & $\begin{array}{l}12.1 \\
22.1 \\
7.7\end{array}$ & $\begin{array}{l}2.21 \\
1.92 \\
0.37\end{array}$ & $\begin{array}{l}5.77 \\
6.50 \\
5.56\end{array}$ & $\begin{array}{r}98.3 \\
103.9 \\
112.4\end{array}$ & 0.106 \\
\hline
\end{tabular}

son. The velocity pulse of the near-fault ground motion is found to be significant as compared to the far-field ground motion. The near-fault ground motions possess significantly long-period velocity pulse, and it is quite distinct from other long-period ground motions; such as those resulting from soft-soil effects or basin response.
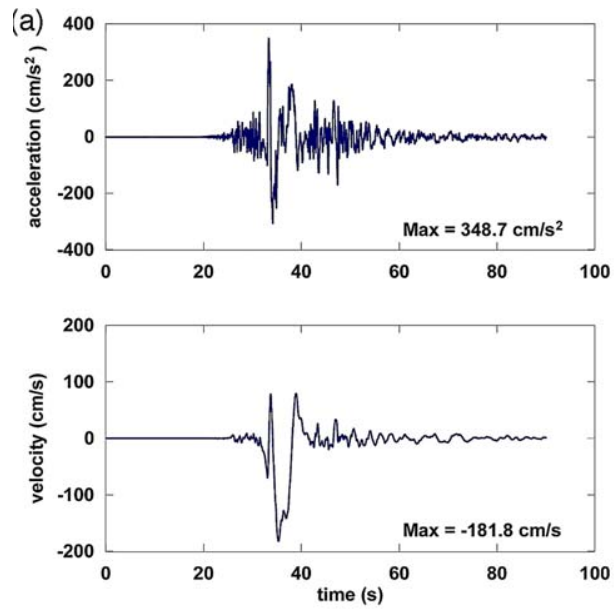

Fig. 5 presents the normalized acceleration response spectra of the near-fault ground motions described in Table 2. The mean acceleration response spectrum of three far-field ground motion records recorded at the same site is also shown in the same figure. It can be clearly seen that the long period responses of the nearfault ground motions are higher than those from the input far-field ground motions. This phenomenon indi-
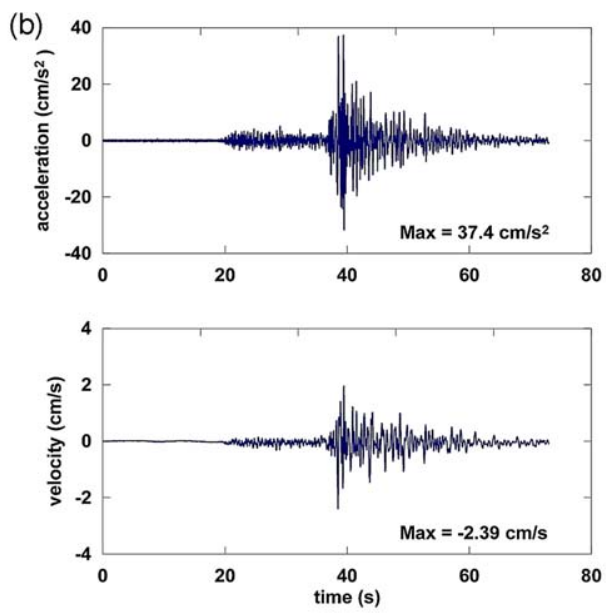

Fig. 4. Acceleration and velocity time histories for (a) near-fault ground motion recorded at station TCU052 in Chi-Chi earthquake, and (b) far-field ground motion (TCU052F1) recorded at same station from other event. 


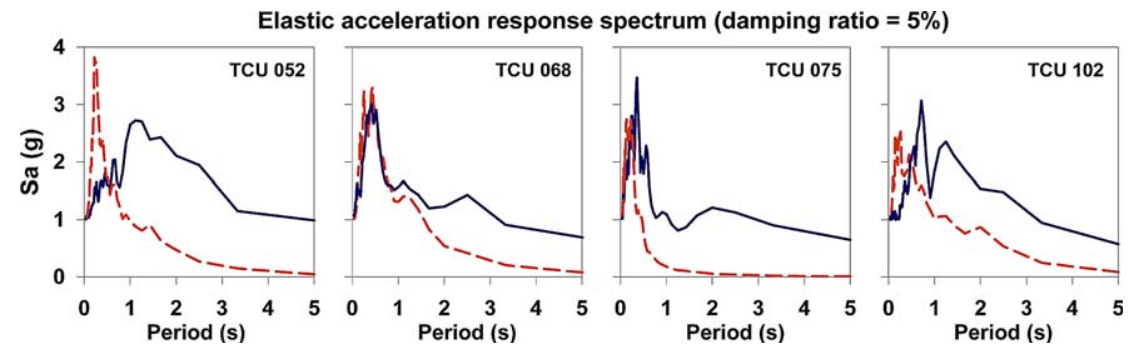

Fig. 5. Comparison of the normalized acceleration spectra (PGA of ground motions scaled to $1 \mathrm{~g}$ ) for near-fault ground motion input (solid line) and that of far-field ground motion input (dash line).

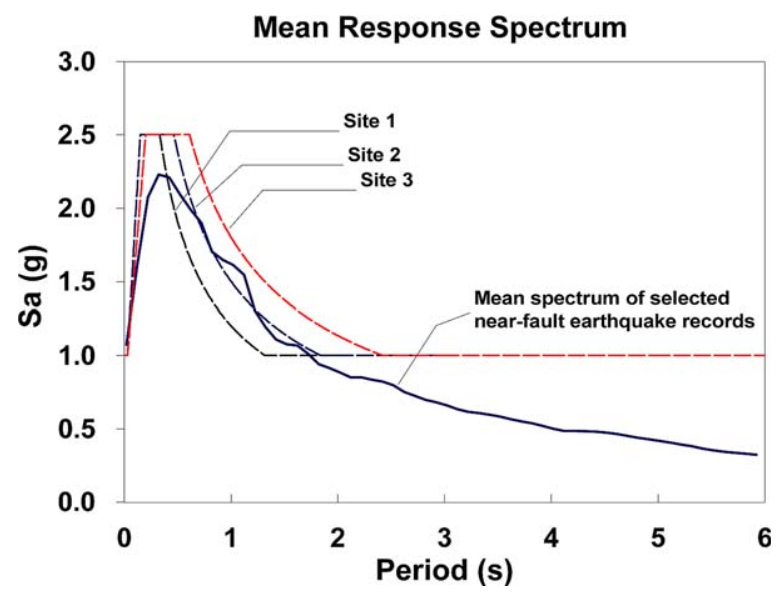

Fig. 6. Comparison of the normalized mean response spectra of four-selected near-fault earthquake records that are shown in Table 2 to the design spectrum of the Taiwan bridge code for different sites. cates that a long-period structure will experience a higher dynamic response when subjected to near-fault ground motion. Fig. 6 shows the comparison of mean response spectra of selected near-fault earthquake records to the design spectrum for different site conditions, the site conditions are classified according to the Taiwan seismic design specifications of highway bridges. In the long-period (displacement sensitive) region, the Taiwanese design response spectrum [11] specifies a spectral acceleration equal to the PGA.

In order to study the isolation effect of an isolated bridge, the response of the bridge is analyzed in the longitudinal direction independently; the dynamic responses in the transverse and vertical directions are ignored. The peak ground acceleration of near-fault records and far-field records are scaled to the design level $(\mathrm{PGA}=0.34 \mathrm{~g})$, and the east-west component of the earthquake ground motion records are utilized in the present analysis. Fig. 7 illustrates the base shear
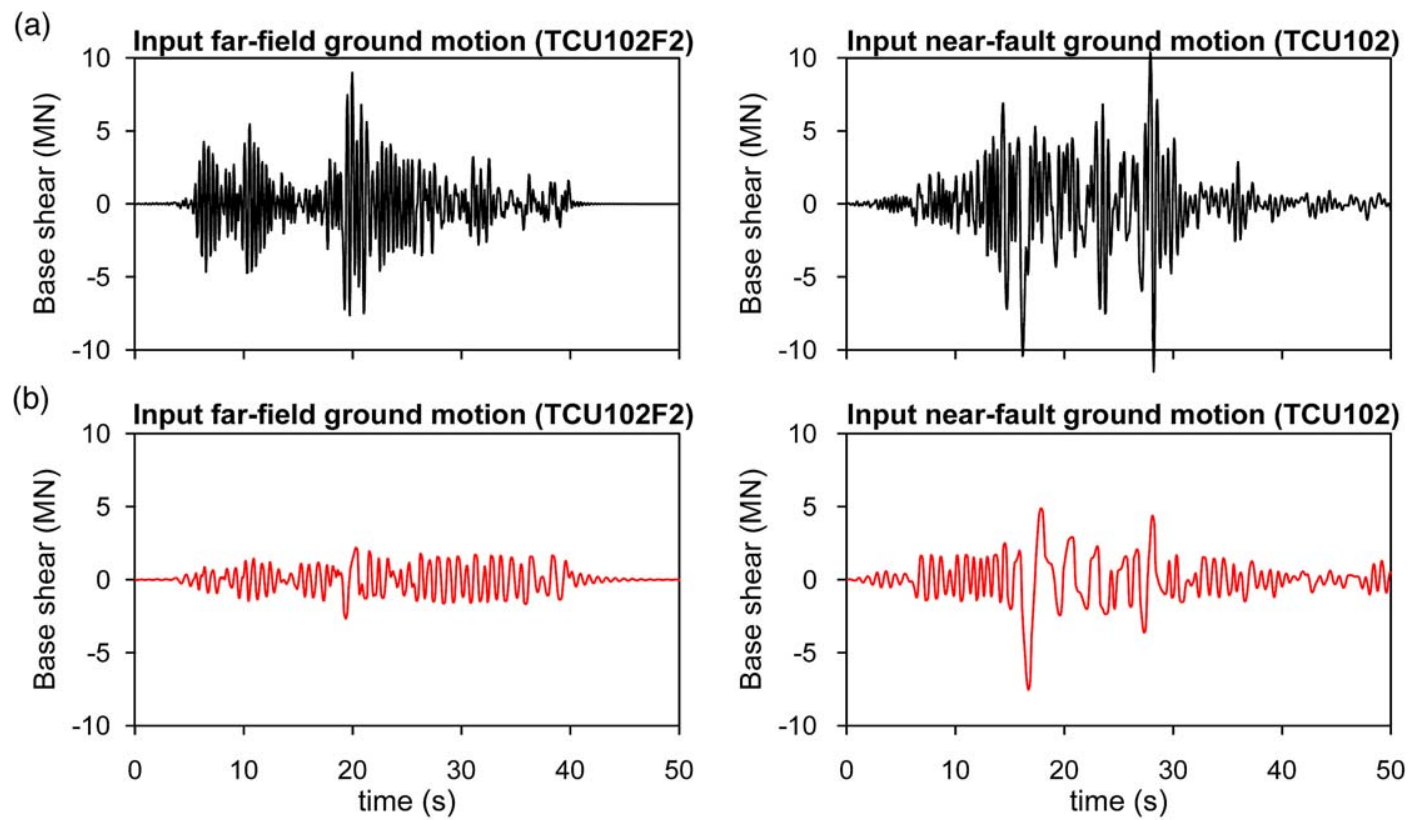

Fig. 7. Responses of base shear in the longitudinal direction for the (a) non-isolated bridge-A, and (b) isolated bridge-A subjected to near-fault and far-field ground motion that are recorded at station TCU102 with PGA $=0.34 g$. 
responses in the longitudinal direction of the isolated bridge- $\mathrm{A}$ and the non-isolated bridge- $\mathrm{A}$ by input nearfault and far-field ground motions. Fig. 8 shows the corresponding results for bridge- $\mathrm{B}$. The base shear is defined as the sum of the shear forces in all piers. The far-field ground motions. The input ground motions are also from the station TCU102, and the PGA is scaled to $0.34 \mathrm{~g}$. In addition to the girder displacement, for the isolated bridge it is also interesting to know the distortions of the LRB under earthquake
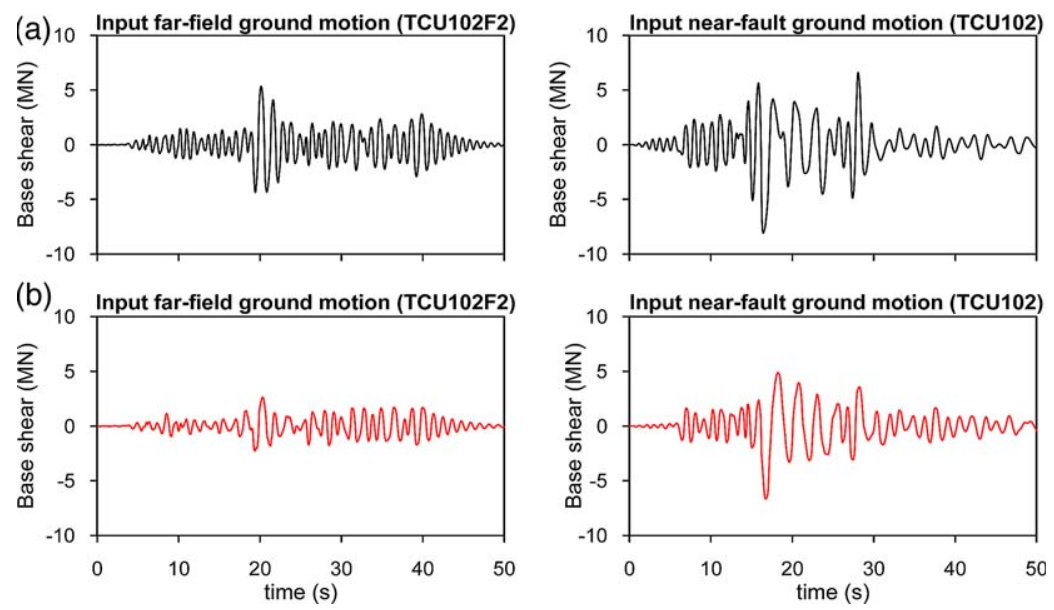

Fig. 8. Responses of base shear in the longitudinal direction for the (a) non-isolated bridge-B, and (b) isolated bridge-B subjected to near-fault and far-field ground motion that are recorded at station TCU102 with PGA $=0.34 g$.

input ground motions for these examples are from station TCU102. In the case of the far-field ground motion, the isolated bridge significantly reduces the base shear responses as compared to the non-isolated bridge. For the case of input near-fault ground motion, the effect in base shear reduction by the bridge isolation is not so significant as that in the case of the far-field ground motion. Fig. 9 shows the longitudinal displacement responses of the girder for the non-isolated bridge and isolated bridge subjected to near-fault and excitation. Fig. 10 shows the time histories of lateral drift of the LRB at the top of pier 1 for the isolated bridge- $\mathrm{A}$ and bridge- $\mathrm{B}$ by input far-field ground motion with label TCU102F2. Fig. 11 shows the lateral drift responses of the LRB by input near-fault ground motion recorded at station TCU102. Figs. 911 show that the longitudinal displacement response of the girder and the lateral drift of the isolator induced by near-fault ground motions is higher than those by far-field ground motions.
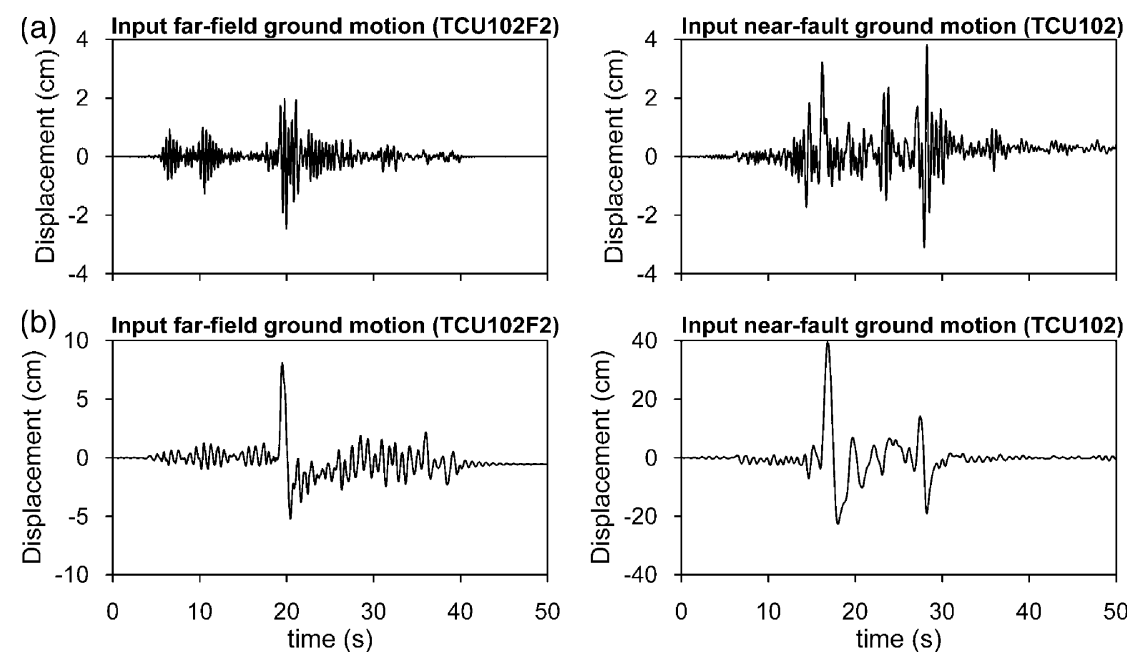

Fig. 9. Responses of longitudinal displacement at the girder for the (a) non-isolated bridge-A, and (b) isolated bridge-A (short-period) subjected to near-fault and far-field ground motion that are recorded at station TCU102 with PGA $=0.34 g$. 

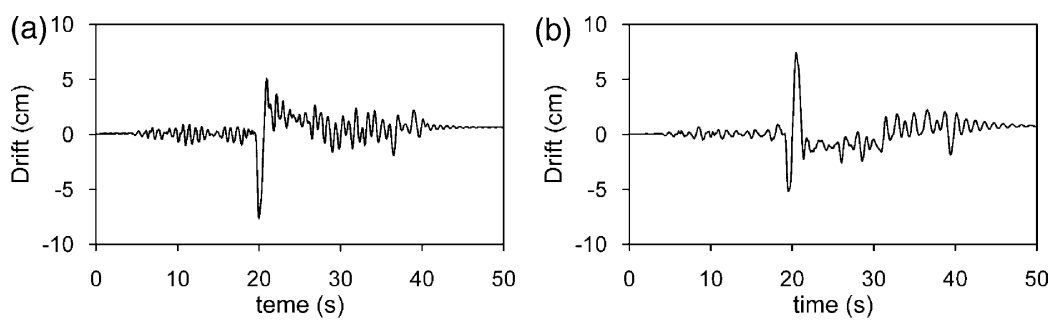

Fig. 10. Responses of lateral drift of the lead-rubber bearing isolator for (a) isolated bridge-A (short-period), and (b) isolated bridge-B (intermediate-period) by input far-field ground motion (label TCU102F2) with PGA $=0.34 g$.
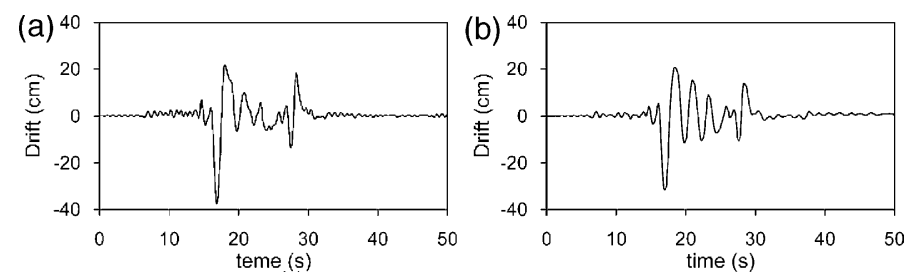

Fig. 11. Responses of lateral drift of the lead-rubber bearing isolator for (a) isolated bridge-A (short-period), and (b) isolated bridge-B (intermediate-period) by input near-fault ground motion from station TCU102 with PGA $=0.34 g$.

Table 4

Maximum base shear (MN) induced by input near-fault and far-field ground motion for bridge-A

\begin{tabular}{|c|c|c|c|c|c|c|}
\hline \multirow[t]{2}{*}{ Station } & \multicolumn{3}{|c|}{ Input near-fault ground motion } & \multicolumn{3}{|c|}{ Input far-field ground motion (mean value) } \\
\hline & $V_{\mathrm{nis}}{ }^{\mathrm{a}}$ & $V_{\text {iso }}{ }^{\mathrm{a}}$ & $V_{\text {iso }} / V_{\text {nis }}$ & $V_{\text {nis }}$ & $V_{\text {iso }}$ & $V_{\text {iso }} / V_{\text {nis }}$ \\
\hline TCU052 & 10.599 & 9.311 & 0.88 & 9.497 & 2.524 & 0.27 \\
\hline TCU068 & 12.614 & 5.446 & 0.43 & 11.626 & 3.131 & 0.27 \\
\hline TCU075 & 10.378 & 5.885 & 0.57 & 5.660 & 1.224 & 0.22 \\
\hline TCU102 & 11.467 & 7.525 & 0.66 & 9.500 & 3.198 & 0.34 \\
\hline
\end{tabular}

${ }^{a}$ The symbol $V_{\text {iso }}$ and $V_{\text {nis }}$ represent the base shear of the isolated bridge and non-isolated bridge, respectively.

Table 4 shows the maximum base shear responses of the isolated bridge-A and non-isolated bridge-A subjected to the near-fault and far-field ground motions. Table 5 shows the corresponding results for bridge-B. The symbol $V_{\text {iso }}$ and $V_{\text {nis }}$ represent the base shear of the isolated bridge and non-isolated bridge, respectively. For input far-field ground motions, the base shear for each site listed in these tables is the mean value from three far-field records. The ratios of $V_{\text {iso/ }}$
$V_{\text {nis }}$ are also shown in this table, which is the index to display the effect in base shear reduction of a seismic isolated bridge. Tables 6 and 7 show the maximum longitudinal displacement responses of the isolated bridge $\left(d_{\text {iso }}\right)$ and non-isolated bridge $\left(d_{\text {nis }}\right)$ subjected to the near-fault and far-field ground motions, respectively. The displacements are measured at the center of the continuous girder (point A in Fig. 1). From these tables, the following observations can be made:

Table 5

Maximum base shear (MN) induced by input near-fault and far-field ground motion for bridge-B

\begin{tabular}{|c|c|c|c|c|c|c|}
\hline \multirow[t]{2}{*}{ Station } & \multicolumn{3}{|c|}{ Input near-fault ground motion } & \multicolumn{3}{|c|}{ Input far-field ground motion (mean value) } \\
\hline & $V_{\text {nis }}$ & $V_{\text {iso }}$ & $V_{\text {iso }} / V_{\text {nis }}$ & $V_{\text {nis }}$ & $V_{\text {iso }}$ & $V_{\text {iso }} / V_{\text {nis }}$ \\
\hline TCU052 & 7.819 & 7.857 & 1.00 & 3.669 & 2.405 & 0.66 \\
\hline TCU068 & 7.160 & 5.614 & 0.78 & 5.850 & 3.060 & 0.52 \\
\hline TCU075 & 5.837 & 5.951 & 1.02 & 1.231 & 1.037 & 0.84 \\
\hline TCU102 & 8.041 & 6.639 & 0.83 & 5.020 & 3.283 & 0.65 \\
\hline
\end{tabular}


Table 6

Maximum longitudinal displacement $(\mathrm{cm})$ of the bridge girder by input near-fault and far-field ground motions for bridge-A

\begin{tabular}{|c|c|c|c|c|c|c|}
\hline \multirow[t]{2}{*}{ Station } & \multicolumn{3}{|c|}{ Input near-fault ground motion } & \multicolumn{3}{|c|}{ Input far-field ground motion (mean value) } \\
\hline & $d_{\text {nis }}{ }^{\mathrm{a}}$ & $d_{\text {iso }}{ }^{\mathrm{a}}$ & $d_{\text {iso }} / d_{\text {nis }}$ & $d_{\text {nis }}$ & $d_{\text {iso }}$ & $d_{\text {iso }} / d_{\text {nis }}$ \\
\hline TCU052 & 3.3 & 51.3 & 15.5 & 2.93 & 7.33 & 2.50 \\
\hline TCU068 & 6.0 & 26.1 & 4.35 & 4.07 & 10.70 & 2.63 \\
\hline TCU075 & 3.1 & 28.7 & 9.26 & 1.30 & 1.30 & 1.00 \\
\hline TCU102 & 3.8 & 39.4 & 10.4 & 3.27 & 11.47 & 3.51 \\
\hline
\end{tabular}

${ }^{\text {a }}$ The symbol $d_{\text {iso }}$ and $d_{\text {nis }}$ represent the maximum displacement of the isolated bridge and non-isolated bridge, respectively.

Table 7

Maximum longitudinal displacement $(\mathrm{cm})$ of the bridge girder by input near-fault and far-field ground motions for bridge-B

\begin{tabular}{|c|c|c|c|c|c|c|}
\hline \multirow[t]{2}{*}{ Station } & \multicolumn{3}{|c|}{ Input near-fault ground motion } & \multicolumn{3}{|c|}{ Input far-field ground motion (mean value) } \\
\hline & $d_{\text {nis }}$ & $d_{\text {iso }}$ & $d_{\text {iso }} / d_{\text {nis }}$ & $d_{\text {nis }}$ & $d_{\text {iso }}$ & $d_{\text {iso }} / d_{\text {nis }}$ \\
\hline TCU052 & 45.2 & 73.4 & 1.62 & 9.17 & 9.63 & 1.05 \\
\hline TCU068 & 24.1 & 36.8 & 1.53 & 14.5 & 14.0 & 0.97 \\
\hline TCU075 & 12.7 & 40.6 & 3.19 & 1.30 & 1.60 & 1.23 \\
\hline TCU102 & 47.3 & 51.0 & 1.08 & 12.9 & 15.9 & 1.23 \\
\hline
\end{tabular}

1. The effects in base shear reduction of a seismic isolated bridge with the far-field ground motion input is more significant than those with the near-fault ground motion input. For isolated bridge-B subjected to near-fault ground motions, there is nearly no effect in the base shear reduction.

2. For both the isolated bridge and non-isolated bridge, near-fault ground motion input causes larger base shear responses than the far-field ground motion.

3. The short-period isolated bridge (bridge-A) has more effect in base shear reduction than the intermediate-period isolated bridge (bridge-B).

4. The displacement responses for the isolated bridge subjected to near-fault ground motion is very large compared with the non-isolated bridge. For far-field ground motion input, the displacement responses for both the isolated and non-isolated bridges are kept in a reasonable range.

\section{Bridge response behavior-earthquake characteristics}

Another objective of this paper is to study the parameters of the near-fault earthquake records which govern the dynamic response of the isolated bridge. For this purpose, a set of 22 near-fault earthquake records is used. The peak ground acceleration of the east-west component of these records is scaled to the design level $(\mathrm{PGA}=0.34 \mathrm{~g})$ for the analysis and some properties of these records are listed in Table 8 .
The following parameters are studied to understand their effect on the response characteristics of the isolated bridge: $\mathrm{PGV} / \mathrm{PGA}$ value, the energy of the ground motion $\left(E_{\mathrm{i}}\right)$ and normalized spectral velocity $\left(S_{\mathrm{v}}\right)$. The energy of the ground motion $\left(E_{\mathrm{i}}\right)$ is defined as follows:

$E_{\mathrm{i}}=\int_{t_{\mathrm{b}}}^{t_{\mathrm{e}}} \dot{u}^{2} \mathrm{~d} t$

where $t_{\mathrm{b}}$ and $t_{\mathrm{e}}$ are the starting time and end time of the strong ground motion, respectively; and $\dot{u}$ is the ground velocity. The normalized spectral velocity $\left(S_{\mathrm{v}}\right)$ listed in Table 8 is calculated at the period $T=0.78 \mathrm{~s}$ for the isolated bridge- $\mathrm{A}$ and at $1.12 \mathrm{~s}$ for the isolated bridge- $\mathrm{B}$, which are the natural periods in the longitudinal direction of those bridges.

Fig. 12 shows the relation between the maximum base shear response and the PGV/PGA value, the energy of the ground motion $\left(E_{\mathrm{i}}\right)$ and the spectral velocity $\left(S_{\mathrm{v}}\right)$ for the isolated bridge-A subjected to the selected 22 near-field ground motion records. Fig. 13 shows the relationship between the displacement responses with $\mathrm{PGV} / \mathrm{PGA}, E_{\mathrm{i}}$ and $S_{\mathrm{v}}$ for the isolated bridge- $\mathrm{B}$. The straight lines in these figures are obtained by linear curve fitting and are used to indicate the trend of calculated data points. From these figures, it can be observed that the maximum base shear tends to increase as the PGV/PGA, $E_{\mathrm{i}}$ and $S_{\mathrm{v}}$ increase for the intermediate-period bridge (bridge-B). This trend does not exist for the short-period isolated bridge (bridge-A). Figs. 14 and 15 show the relationship between the displacement responses with the PGV/ PGA, $E_{\mathrm{i}}$ and $S_{\mathrm{v}}$ for the isolated bridge-A and bridge-B, 
Table 8

Selected near-fault ground motion records for parameter study ( $E_{\mathrm{i}}$ is the energy of the ground motion defined in Eq. (1), $S_{\mathrm{v}}$ is the spectral velocity, and $T$ is the structural period)

\begin{tabular}{|c|c|c|c|c|}
\hline Station & $\mathrm{PGV} / \mathrm{PGA}(\mathrm{s})$ & $E_{\mathrm{i}}(\mathrm{N}-\mathrm{m} / \mathrm{kg})$ & $S_{\mathrm{v}}(\mathrm{m} / \mathrm{s})$ at $T=0.78 \mathrm{~s}$ & $S_{\mathrm{v}}(\mathrm{m} / \mathrm{s})$ at $T=1.12 \mathrm{~s}$ \\
\hline TCU052 & 0.521 & 3.118 & 0.132 & 0.379 \\
\hline TCU054 & 0.322 & 2.048 & 0.302 & 0.330 \\
\hline TCU067 & 0.200 & $\begin{array}{l}2.040 \\
0.394\end{array}$ & 0.250 & 0.361 \\
\hline TCU074 & 0.120 & 0.173 & 0.287 & 0.298 \\
\hline TCU072 & 0.190 & 0.252 & 0.386 & 0.291 \\
\hline TCU075 & 0.358 & 0.874 & 0.120 & 0.150 \\
\hline TCU076 & 0.204 & 0.348 & 0.114 & 0.147 \\
\hline TCU122 & 0.216 & 0.844 & 0.222 & 0.240 \\
\hline TCU049 & 0.208 & 0.512 & 0.125 & 0.225 \\
\hline TCU053 & 0.192 & 0.556 & 0.183 & 0.250 \\
\hline TCU065 & 0.171 & 0.395 & 0.135 & 0.341 \\
\hline TCU068 & 0.558 & 2.666 & 0.157 & 0.292 \\
\hline TCU071 & 0.135 & $\begin{array}{l}2.000 \\
0.215\end{array}$ & 0.216 & 0.226 \\
\hline TCU078 & 0.101 & $\begin{array}{l}0.215 \\
0.123\end{array}$ & 0.207 & 0.165 \\
\hline TCU082 & 0.233 & 1.064 & 0.253 & 0.235 \\
\hline TCU089 & 0.127 & 0.194 & 0.157 & 0.212 \\
\hline TCU102 & 0.290 & $\begin{array}{l}0.194 \\
1.165\end{array}$ & 0.240 & 0.398 \\
\hline TCU120 & 0.280 & 1.017 & 0.260 & 0.385 \\
\hline CHY028 & 0.102 & 0.071 & 0.204 & 0.253 \\
\hline СHY029 & 0.120 & 0.142 & 0.194 & 0.219 \\
\hline CHY025 & 0.323 & 2.400 & 0.232 & 0.429 \\
\hline CHY101 & 0.198 & 0.504 & 0.188 & 0.181 \\
\hline
\end{tabular}

respectively. It can be seen from these figures that the displacement response of bridge-A depends on PGV/ PGA, $E_{\mathrm{i}}$ and $S_{\mathrm{v}}$. The displacement response of bridge$\mathrm{B}$, however, depends on PGV/PGA and $E_{\mathrm{i}}$ only.
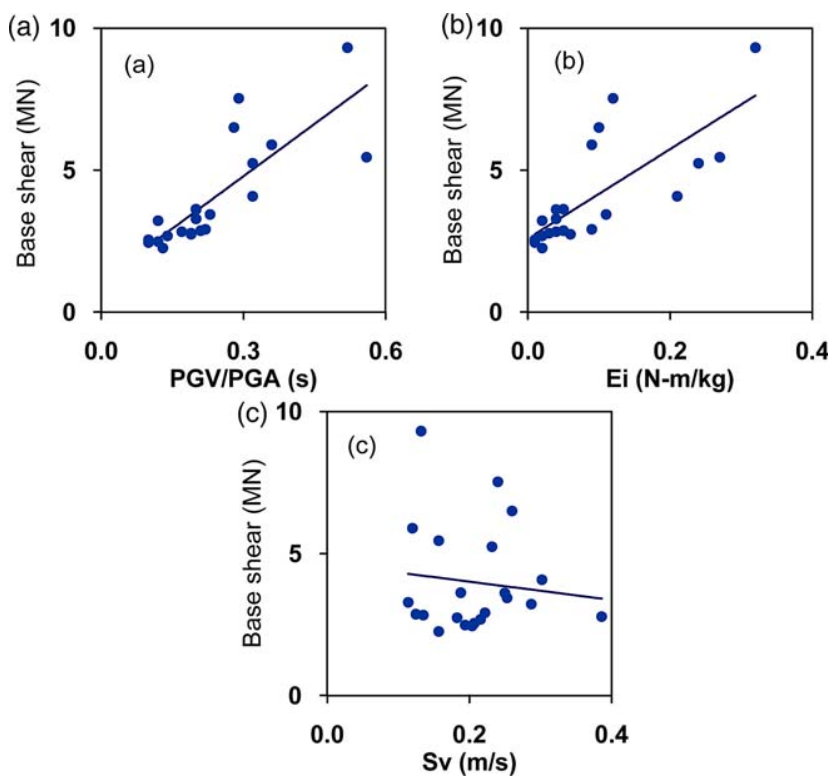

Fig. 12. Relationship between the maximum base shear and (a) $\mathrm{PGV} / \mathrm{PGA}$, (b) energy of the ground motion $E_{\mathrm{i}}$, and (c) spectral velocity $S_{\mathrm{v}}$ at period $T=0.78 \mathrm{~s}$ for the isolated bridge-A (short-period) by input near-fault ground motions that are recorded during the Chi-Chi earthquake.
Figs. 12-15 show that the ground motions with a high $\mathrm{PGV} / \mathrm{PGA}$ value or high energy value $E_{\mathrm{i}}$, will need large seismic demands for the analyzed isolated bridges. These two parameters are independent of the
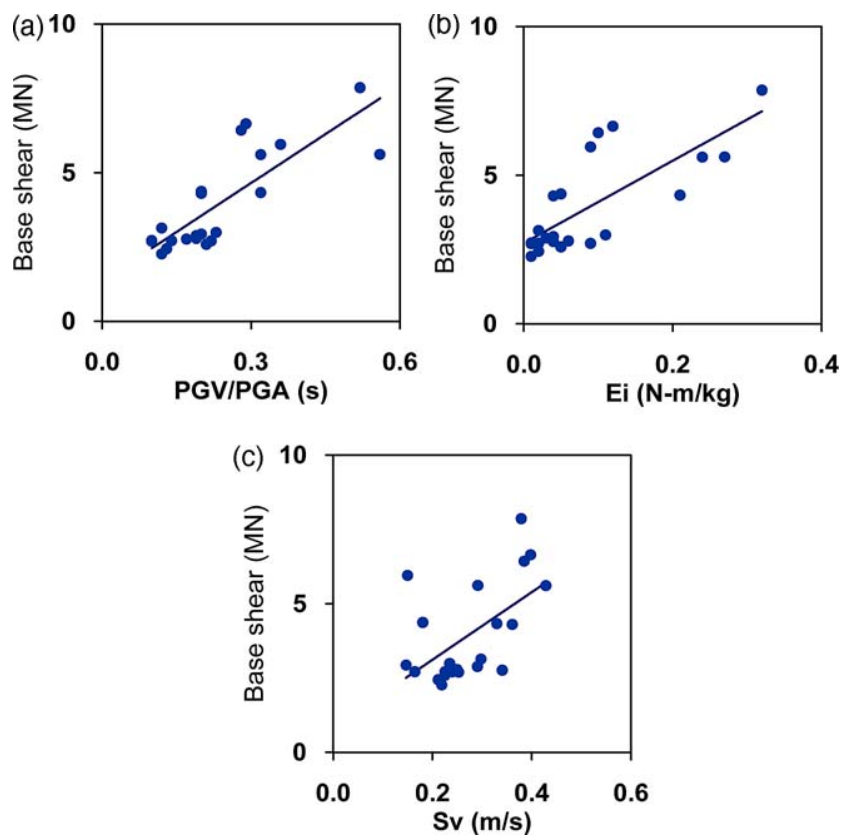

Fig. 13. Relationship between the maximum base shear and the (a) $\mathrm{PGV} / \mathrm{PGA}$, (b) energy of the ground motion $E_{\mathrm{i}}$, and (c) spectral velocity $S_{\mathrm{v}}$ at period $T=1.12 \mathrm{~s}$ for the isolated bridge-B (intermediate-period) by input near-fault ground motions that are recorded during the Chi-Chi earthquake. 

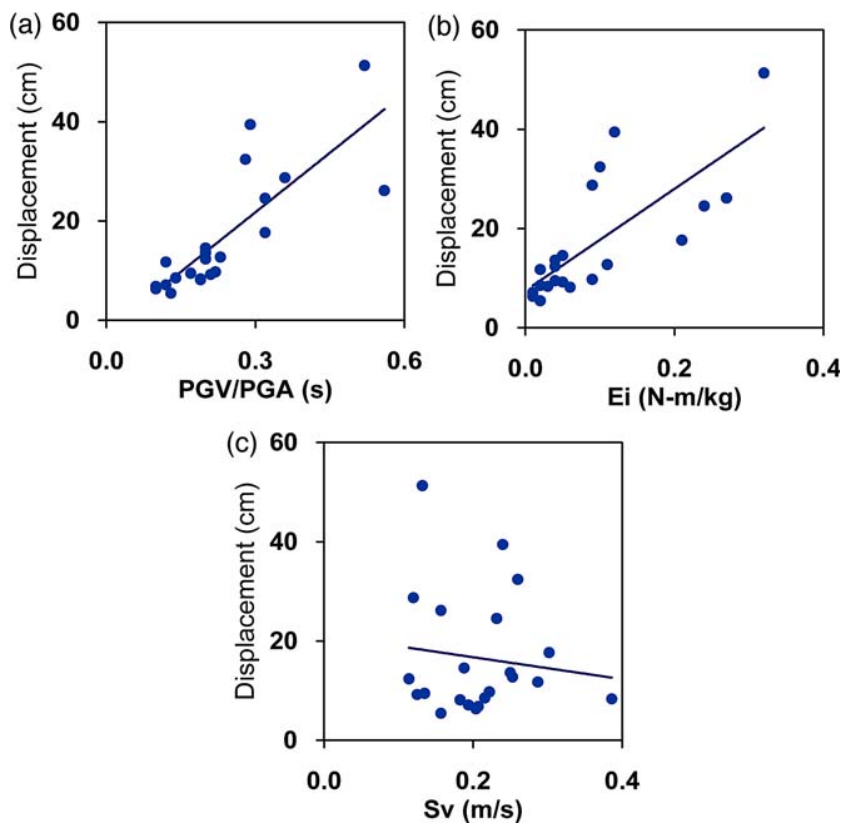

Fig. 14. Relationship between the maximum longitudinal displacement of the girder and (a) PGV/PGA, (b) energy of the ground motion $E_{\mathrm{i}}$, and (c) spectral velocity $S_{\mathrm{v}}$ at period $T=0.78 \mathrm{~s}$ for the isolated bridge-A (short-period) by input near-fault ground motions.

structural period and are associated with the ground motion characteristics only. From Table 8 , it is observed that these two parameters are highly dependent on each other for the near-fault ground motions recorded during the Chi-Chi earthquake. These two
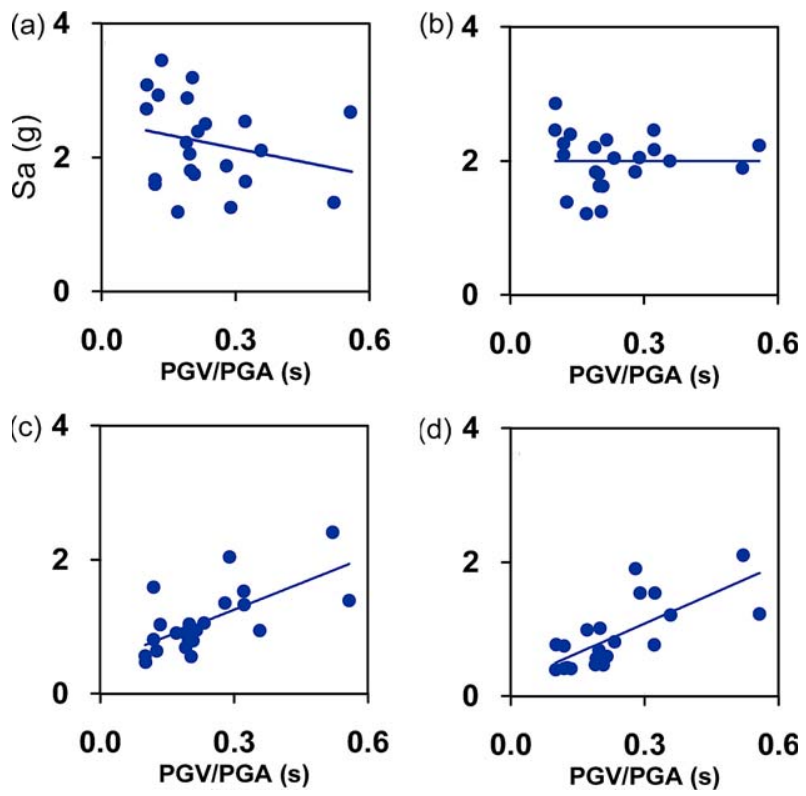

Fig. 16. Relationship between the spectral acceleration $S_{\mathrm{a}}$ and the $\mathrm{PGV} / \mathrm{PGA}$ value for various structural periods $T$ by input near-fault ground motions that are recorded during the Taiwan Chi-Chi earthquake. (a) $T=0.3 \mathrm{~s}$, (b) $T=0.6 \mathrm{~s}$, (c) $T=0.9 \mathrm{~s}$, (d) $T=1.2 \mathrm{~s}$.
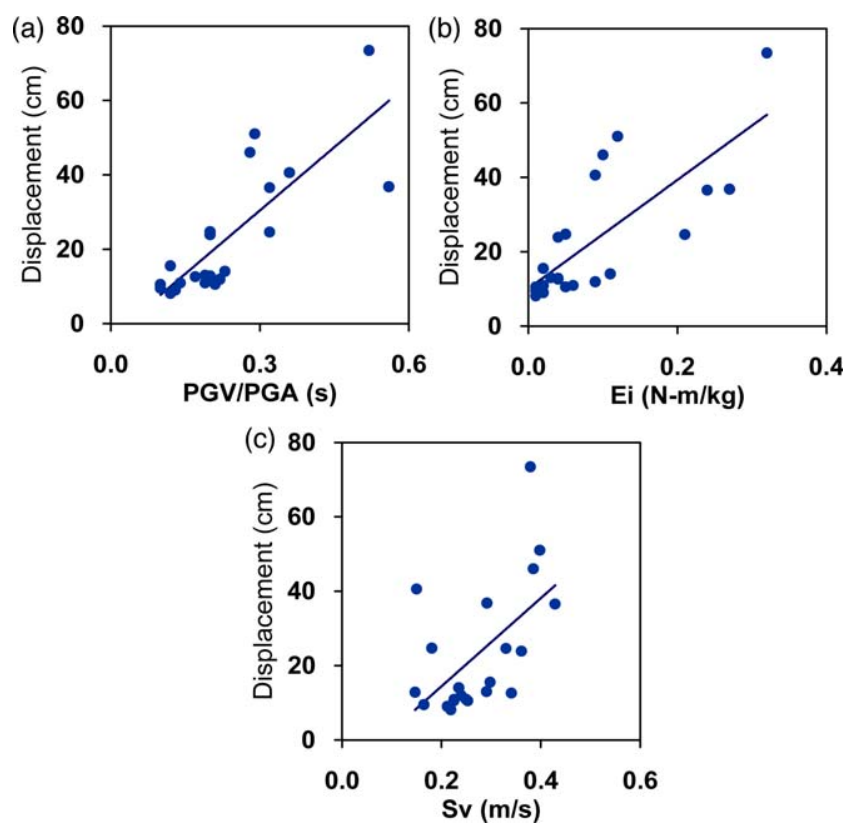

Fig. 15. Relationship between the maximum longitudinal displacement of the girder and (a) PGV/PGA, (b) energy of the ground motion $E_{\mathrm{i}}$, and (c) spectral velocity $S_{\mathrm{v}}$ at period $T=1.12 \mathrm{~s}$ for the isolated bridge-B (intermediate-period) by input near-fault ground motions.

parameters may be treated as a single parameter for those near-fault ground motions. In view of Table 2, Table 3, and Fig. 5, the ground motions with high PGV/PGA value have a wide acceleration-sensitive region in their elastic response spectrum. This will increase the base shear, displacement and ductility demand of isolated bridges, and it is verified by the present analysis. This effect can be explained by Fig. 16, which shows the relation between the $S_{\mathrm{a}}$ value and the PGV/PGA value for different structural periods. In this figure, for a structural period higher than $0.6 \mathrm{~s}$, the $S_{\mathrm{a}}$ value increases as the PGV/PGA value increases, but the short-period structures (period less than $0.6 \mathrm{~s}$ ) do not have such a phenomenon.

It is also interesting to study the reduction effect in base shear for the seismically isolated bridge compared with the non-isolated bridge. The PGV/PGA value of the earthquake records will significantly influence the dynamic response of the bridges. Fig. 17 shows the relationship between the PGV/PGA value and base shear reduction ratio $\left(V_{\text {iso }} / V_{\text {nis }}\right)$ for bridge-A and bridge-B, respectively, where $V_{\text {iso }}$ and $V_{\text {nis }}$ represent the base shear of the isolated bridge and non-isolated bridge, respectively. In this figure, the PGV/PGA value strongly influences the base shear reduction ratio for those analyzed bridges, and it is shown that the base shear reduction effect is very limited if the input ground motions have a high PGV/PGA value. 

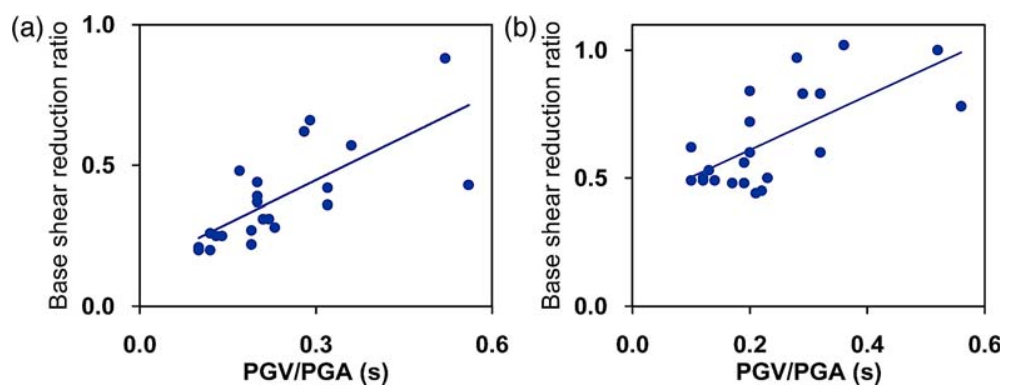

Fig. 17. Relationship between the base shear reduction ratio and the PGV/PGA value for (a) bridge-A (short-period), and (b) bridge-B (intermediate-period) by input near-fault ground motions that are recorded during the Taiwan Chi-Chi earthquake.

\section{Concluding remarks}

A comparison of the non-linear dynamic response characteristics of seismically isolated and non-isolated bridges subjected to near-fault and far-field ground motions is made, and parametric studies for the dynamic responses of seismic isolated bridges are carried out. The ground motions recorded during the Chi-Chi earthquake and other earthquakes are utilized as input to analyze the dynamic behavior of the bridges. The investigation of the dynamic responses of the bridges under near-fault and far-field ground motions has lead to the following conclusions:

1. The effects in base shear reduction of a seismically isolated bridge with the far-field ground motion input is more significant than those with the nearfault ground motion input. For isolated bridge with intermediate-period subjected to near-fault ground motions, there is nearly no effect in the base shear reduction.

2. The displacement and base shear response for both the intermediate-period and short-period isolated bridges strongly depend on the PGV/PGA value and the energy of the ground motion $E_{\mathrm{i}}$. These two parameters are related to each other.

3. The PGV/PGA value is identified as the key parameter that controls the response characteristics of bridges under near-fault ground motion. The base shear and displacement demand of isolated bridges are significantly influenced by this parameter.

\section{Acknowledgements}

The author gratefully acknowledge the financial support granted by the National Science Council (92-2211E-390-006) and National Center for Research on Earthquake Engineering, ROC, and the Central Weather Bureau for providing the earthquake records.

\section{References}

[1] Bertero VV, Mahin SA, Herrera RA. Aseismic design implications of San Fernando earthquake records. Earthquake Engineering and Structural Dynamics 1978;6(1):31-42.

[2] Anderson JC, Bertero VV. Uncertainties in establishing design earthquake. Journal of Structural Engineering, ASCE 1987; 113(8):1709-24.

[3] Hall JF, Heaton TH, Halling MW, Wald DJ. Near-source ground motion and its effects on flexible buildings. Earthquake Spectra 1995;11(4):569-605.

[4] Iwan WD. Drift spectrum: measure of demand for earthquake ground motions. Journal of Structural Engineering, ASCE 1997;123(4):397-404.

[5] Malhotra PK. Response of buildings to near-field pulse-like ground motions. Earthquake Engineering and Structural Dynamics 1999;28:1309-26.

[6] Chopra AK, Chintanapakdee C. Comparing response of SDOF systems to near-fault and far-fault earthquake motions in the context of spectral regions. Earthquake Engineering and Structural Dynamics 2001;30:1769-89.

[7] Chai JF, Loh CH. Near-fault ground motion and its effect on civil structures. Proceedings of the International Workshop on Mitigation of Seismic Effects on Transportation Structures, Taiwan. 1999, p. 70-81.

[8] Liao WI, Loh CH, Wan S, Jean WY, Chai JF. Dynamic responses of bridges subjected to near-fault ground motions. Journal of the Chinese Institute of Engineers 2000;23(4):455-64.

[9] Nakashima M, Matsumiya T, Asano K. Comparison in earthquake responses of steel moment frames subjected to near-fault strong motions recorded in Japan, Taiwan and the US. Proceedings of the International Workshop on Annual Commemoration of Chi-Chi Earthquake, Technology Aspect, Taiwan, vol. II. 2000, p. 112-23.

[10] Loh CH, Wan S, Liao WI. Effects of hystertic model on seismic demands: consideration of near-fault ground motions. The Structural Design of Tall Buildings 2002;11:115-69.

[11] MOTC. Seismic design specifications of highway bridges. Ministry of Transport and Communications in Taiwan; 2002 [in Chinese].

[12] Prakash V, Powell GH. DRAIN-2DX: base program user guide, version 1.10. a computer program distributed by NISEE/computer applications. Department of Civil Engineering, University of California, Berkeley, CA; 1993.

[13] Kent DC, Park R. Flexural members with confined concrete. Journal of Structural Division, ASCE 1971;97(ST7):1969-90.

[14] Yeh YK, Mow YL. Full scale tests on ductility, shear strength and retrofit of reinforced concrete hollow columns (1). Research report, NCREE-99-024, Taipei, Taiwan; 1999 [in Chinese].

[15] Available from: http://www.cwb.gov.tw/. 